\title{
Analysis of the effects of anatomy committee exam stress on visual and auditory reaction time and cortisol level: A neuroperformance study
}

\author{
Deniz Şenol ${ }^{1}$, Cihat Uçar ${ }^{2}$, Ayşegül Kısaoğlü ${ }^{3}$, Mustafa Canbolat ${ }^{3}$, Davut Özbağ $\breve{g}^{3}$, Sedat Yıldız ${ }^{4}$, Şeyma Toy \\ ${ }^{1}$ Department of Anatomy, Faculty of Medicine, Düzce University, Düzce, Turkey \\ ${ }^{2}$ Department of Physiology, Faculty of Medicine, Adlyaman University, Adlyaman, Turkey \\ ${ }^{3}$ Department of Anatomy, Faculty of Medicine, Inönü University, Malatya, Turkey \\ ${ }^{4}$ Department of Physiology, Faculty of Medicine, Inönü University, Malatya, Turkey \\ ${ }^{5}$ Department of Anatomy, Faculty of Medicine, Karabük University, Karabük, Turkey
}

Received: 2021-02-18.

Accepted: 2021-03-25

This work is licensed under a

Creative Commons Attribution 4.0 International License

J Clin Med Kaz 2021; 18(3):30-34

Corresponding author:

Dr. Deniz ŞENOL.

E-mail: denizanatomi@gmail.com

\section{Abstract}

Objective: The present study aims to find out the effects of exam stress, which exists in every moment of education life, on visual and auditory reaction time (VRT, ART), cortisol level and stress perception.

Material and methods: A total of 66 students (36 males, 30 females) were included in the study. VRT and ART measurements were carried out with reaction timer by asking the participants to use their dominant hands. Reaction times were recorded on two occasions, namely 30 days before the committee exam (relaxed period) and, again, on the day of exam (stressed period). Additionally, students provided salivary samples and filled in State Trait Anxiety Inventory-I on both occasions.

Results: Median values of cortisol, STAI-I, VRT and ART scores of male and female students were higher during stress period than that of the relaxed period $(p<0.05)$. Correlation analysis showed a positive weak correlation between cortisol level and STAI-I scores of students in exam period (male: $r=0.317, p<0.05$; female: $r=0.253, p<0.05$ ). Moreover, cortisol levels were positively correlated with VRT (male: $r=0.155, p<0.05$; female: $r=0.227, p<0.05$ ) and ART (male: $r=0.159, p<0.05$; female: $r=0.163, p<0.05$ ) scores both male and female students.

Conclusion: The results show that stress increase was found to increase cortisol level and STAI-I scores. Increased cortisol level was associated with longer reaction times as measured by VRT and ART.

Keywords: stress, reaction time, saliva, cortisol, neuroperformance

\section{Introduction}

In our daily lives, stress is everywhere. Stress can balance behavioural and hormonal reactions [1,2] and radically change neural responses given to information received $[3,4]$. Acute stress has a considerable influence on various cognitive processes including attention, cognitive control, memory and social cognition $[5,6]$.

Stressful encounters and also individuals' psychological reactions to these encounters activate the hypothalamic-pituitary-adrenocortical (HPA) axis and the sympathetic nervous system, causing excessive levels of stress hormones, especially cortisol and catecholamines, to be secreted. When stress hormones are secreted, bodily functions, especially immune, cardiovascular and metabolic functions may undergo dysregulation [7]. One of the naturalistic stressor examples is academic exams. These exams are time-limited and generally considered to be aversive and they are seen as psychological and physiological 
reactions to stressful encounters. Based on cognitive theories of stress, the present study analyses the effects of cognitive appraisals of stress in exam situation and test anxiety. According to cognitive approach, the individual who has coping sources to cope with a stressful situation evaluates the threat or challenge in the stressful situation through cognitive processing in stressful encounters like academic exams [8]. The coping strategies individuals use in the face of stressful situations affect their evaluations and determine the psychological (e.g., experienced stress, test anxiety) and physiological results of the encounter. In addition to cognitive aspects (i.e., worry) and the elements of emotional and physiological arousal (i.e., emotionality), test anxiety includes particular cognitive, emotional and physiological reactions caused by the stimuli of testing [9-11]. In every stage of our lives, we are faced with decisions that we have to make. The speed, quality and hit rates of the decision made are the most important parameters of success. The stressful environment an individual is in has negative influences on the individual's biological and psychological state. This stress experienced causes carelessness and low concentration, low performance and inefficiency [12-14].

Reaction time (RT) is the time between the presentation of a sensory stimulus and the following behavioural reaction $[15,16]$. RT is closely associated with the speed of making a decision [17]. For a move fit for the purpose, sensory and motor systems should be working in coordination. In humans, reaction speed is a direct indicator of nerve transmission speed. RT is different from reflex time, which is the automatical response given to an external stimulus. It is a completely voluntary situation in which central nervous system is enabled [18]. Characteristics such as the transmission speed of the nerves which have a role in the stimulus reaching the central nervous system and the response being carried to the effector organ and the effector muscle being a fast or slow muscle creates differences of milliseconds from person to person [18].

A great number of studies report RT being influenced by stress and anxiety $[19,20]$. Stress is present in every moment of our education life. The idea that stress can affect the reaction is the hypothesis of our study. This study aims to examine the effects of exam stress, which exists in every moment of students' educational life and influences students negatively most of the time, on visual and auditory RT (VRT-ART) and cortisol level.

\section{Material and methods \\ Participants}

The study includes 66 students (36 males, 30 females; mean age $19.4 \pm 1.8$ years; range, 18 to 20 years) who were studying at Inönü University, Faculty of Medicine between May 2018 and June 2018 and who signed informed consent form.

Inclusion criteria consisted of the following: being physically healthy, not having any medical obstacles to prevent participation in the study, not having any disease, no previous history of orthopaedic surgery, not having performed resistance exercise at least six months before the start of the study, not using food supplement, such as keratin during the study. Antidepressant drug and herbal relaxant use before the stressed and relaxed periods were exclusion criteria.

Students using hearing aids and contact lenses and glasses were not included in the study. Female students in menstrual cycle or those to enter this cycle in three days were also excluded [21]. Malatya Clinical Researches Ethical Board (2018/110) approved the study protocol and the principles of the Declaration of Helsinki were followed. Participants were informed about the study and an informed consent form was signed.
The relaxed period was accepted as the period 30 days before the committee exam and the first RT measurements and saliva samples were taken then. The stressed period was the day of the committee exam and the second RT measurements and saliva samples were taken. Since we thought that students would have high levels of stress before the test, this period was considered stressed. State Trait Anxiety Inventory-I (STAI-I) and cortisol measurements were used to support this hypothesis. There was a period of 30 days between the relaxed period and the stressed period. All students were given STAI-I, a commonly used scale in the assessment of anxiety, during the relaxed and stressed periods. Öner and Le Compte conducted the validity and reliability of STAI-I's Turkish version [22]. Classification of the points was as follows in STAI-I scale: $\leq 36$ as "no anxiety", 37-42 as "mild anxiety", $\geq 42$ as "high anxiety".

\section{RT measurements}

Hubbard Scientific Reaction Timer (Model: 6027, USA) was used to make VRT and ART measurements. Two different warnings as visual (light) and auditory (sound) are obtained from Reaction Timer device. RT measurements were performed in a noise free environment with sufficient light between 09:30 and 11:00. Each subject was asked to put their dominant hands on a table in front of them which had a button and a Reaction Timer $10 \mathrm{~cm}$ away from the button. With "ready" command, either sound or light stimulant was given and the subjects were asked to press the buttons in shortest time in accordance with the stimulants. Each subject made 10 trials for sound and light stimuli, the first of which was taken as practice. The average of the last trials was determined as RT [23].

\section{Analysis of cortisol in saliva}

In order to minimize the impact of extra test components on cortisol levels, the subjects were told to avoid smoking, caffeine, and physical exertion for 3 hours before coming to their appointment, in the preliminary information provided, that all samples should be given at 10:00 (am). They were asked to eat a low fat and protein meal and not eat or drink for 1 hour before coming to their appointment. Passive droll method was used to collect saliva samples, as shown by Granger et al. [24]. Samples were kept in a laboratory freezer at $-20{ }^{\circ} \mathrm{C}$. After thawing, the samples were centrifuged at $4000 \mathrm{~g}$ for $10 \mathrm{~min}$ and supernatant was used for ELISA analyses. Samples were diluted 1:5 and assayed in triplicate with assay buffer. ELISA procedure; Cortisol-BSA stock solution $(1 \mathrm{mg} / \mathrm{mL})$ was diluted with carbonate buffer, $\mathrm{pH}$ 9.6 before adding to a 96-well microtiter plate at $200 \mu \mathrm{L} /$ well. For one night, the microtiter plate was incubated at $+4{ }^{\circ} \mathrm{C}$ and washed five times with wash buffer and eight-channel pipette. With blocking buffer $(200 \mu \mathrm{L} /$ well $)$, binding places that had no coating antigen were blocked at $37^{\circ} \mathrm{C}$ for $2 \mathrm{~h}$. After washing, standard solutions or samples $(40 \mu \mathrm{L} /$ well $)$ and diluted $1 \mathrm{st} \mathrm{Ab}$ (antiserum) $(40 \mu \mathrm{L} /$ well $)$ were put in duplicate and incubated for $45 \mathrm{~min}$ at $37^{\circ} \mathrm{C}$. Later, after the washing process, following the addition of biotinylated anti-Rabbit antibody $(100 \mu \mathrm{L} /$ well), the plate was incubated for $30 \mathrm{~min}$ at $37^{\circ} \mathrm{C}$. After washing for 5 times, the plate was incubated at $+4{ }^{\circ} \mathrm{C}$ for 15 min following the addition of streptavidin peroxidase solution $(100 \mu \mathrm{L} /$ well $)$. Next, after the plate was washed for another 5 times, substrate solution $(150 \mu \mathrm{L} /$ well $)$ was added and incubated in dark for $10 \mathrm{~min}$. Stop solution $(50 \mu \mathrm{L} /$ well) was added after incubation and microplate reader was used to measure absorbance at $450 \mathrm{~nm}$. While intraassay variation $(\mathrm{CV})$ was found as $5.6 \%$, inter-assay variation was found as $7.8 \%$. Elisa test was made by the same expert in the same laboratory [21]. 


\section{Statistical analysis}

Normality assumption of the data was tested with Kolmogorov Smirnov test. The data without normal distribution were analysed with Wilcoxon paired samples test. Spearman Rho coefficient was used to calculated the correlations. Significance was considered at $p<0.05$ level and IBM SPSS Statistics 22.0 for Windows program was used. In calculating the sample size, the 95\% confidence interval in the G-Power 3.1.7 package program was calculated for the paired samples $t$ test. For determining at least $1 \mathrm{~ms}$ of change in RT, minimum sample size for $\alpha=0.05$ and 1 -beta $=0.80$ was calculated to be 52 with the effect size estimated as 0.40 .

\section{Results}

According to the results of the analysis we conducted, cortisol level and STAI-I score median values were found to increase in the stressed period when compared with the relaxed period. Wilcoxon paired-samples test was given to the data to determine whether there were changes in cortisol and STAI-I scores during transition from relaxed period to the stressed period. Analysis results showed that the increase in cortisol level and STAI-I scores of both men and women during transition from relaxed period to the stressed period was statistically significant $(p<0.05)$. According to Spearman rho correlation analysis of cortisol and STAI-I scores in exam period, a positive weak correlation was found in both male $(\mathrm{r}: 0.317, \mathrm{p}<0.05)$ and female (r:0.253, $\mathrm{p}<0.05)$ students (Table 1).

\begin{tabular}{|c|c|c|c|c|c|c|c|c|}
\hline \multirow{3}{*}{ Sex } & \multicolumn{8}{|c|}{$\begin{array}{l}\text { Median (Min-Max) values of cortisol and STAI-I, Wilcoxon paired-samples test results between relaxed and stressed, } \\
\text { Spearman rho correlation analysis results between cortisol level and STAI-I in exam period }\end{array}$} \\
\hline & Variables & Relaxed & & Stressed & & $\mathrm{p}$ & \multirow{2}{*}{$\begin{array}{l}\text { Exam Period } \\
\text { Correlation }\end{array}$} & \\
\hline & & Median & Min-Max & Median & Min-Max & & & Cortisol \\
\hline \multirow[t]{2}{*}{ Male } & Cortisol & 14.7 & $2.9-58.3$ & 24.5 & 8.8-196 & .013 & \multirow[t]{4}{*}{ STAI-I* } & r: .317 \\
\hline & STAI-I* & 46 & $32-70$ & 55 & $31-76$ & .041 & & p: .025 \\
\hline \multirow[t]{2}{*}{ Female } & Cortisol & 14.9 & $3.4-61.5$ & 27.5 & 7.91-779.7 & .019 & & r: .253 \\
\hline & STAI-I & 43 & $27-67$ & 50 & $28-77$ & .042 & & p: .018 \\
\hline
\end{tabular}

*STAI-I: State Trait Anxiety Inventory-I

According to the Wilcoxon paired-samples test results, both VRT and ART were found to increase statistically significantly during transition from relaxed period to the stressed period $(p<0.05)$, (Table 2). With these data, it can be concluded that VRT and ART increase as stress increases.

\section{Table 2}

Median (Min-Max) values of VRT and ART measurements and Wilcoxon paired-samples test results between relaxed and stressed

\begin{tabular}{lllllll}
\hline \multirow{2}{*}{ Sex } & Variables & \multicolumn{3}{c}{ Relaxed } & \multicolumn{3}{c}{ Stressed } & \multirow{2}{*}{$\mathrm{p}$} \\
\cline { 3 - 6 } Male & & Median & Min-Max & Median & Min-Max & \\
& VRT $^{*}$ & 31.6 & $24.6-44.3$ & 35.6 & $28.3-54.6$ & .008 \\
\multirow{2}{*}{ Female } & ART $^{* *}$ & 37.6 & $27.6-51$ & 41.3 & $27.3-60.6$ & .007 \\
& VRT $^{*}$ & 32.6 & $23.6-44$ & 41.3 & $27.6-51.6$ & .003 \\
& ART $^{* *}$ & 36.3 & $24.6-51$ & 40.3 & $26.3-51.3$ & .011 \\
\hline
\end{tabular}

*VRT: Visual reaction time

**ART: Auditory reaction time

Spearman's rho correlation analysis was performed to determine how VRT and ART values differed with Cortisol and STAI-I scores (Table 3). According to the results of the analysis conducted, a positive and weak correlation was found between VRT and ART and cortisol level and STAI-I scores in both male and female students (Table 3).

\begin{tabular}{|c|c|c|c|c|c|c|c|c|}
\hline \multicolumn{2}{|c|}{ Table 3} & \multicolumn{7}{|c|}{$\begin{array}{l}\text { Spearman rho correlation analysis results } \\
\text { conducted on the VRT and ART scores }\end{array}$} \\
\hline \multirow[t]{2}{*}{ Variables } & \multirow{2}{*}{\multicolumn{2}{|c|}{$\begin{array}{l}\text { Test } \\
\text { statistics }\end{array}$}} & \multicolumn{3}{|c|}{ Male } & \multicolumn{3}{|c|}{ Female } \\
\hline & & & Cortisol & STA & & Cort & & STAI-I \\
\hline \multirow[t]{2}{*}{ VRT* } & r & & .155 & .31 & & .227 & & .348 \\
\hline & $\mathrm{p}$ & & .048 & .03 & & .046 & & .011 \\
\hline \multirow[t]{2}{*}{$\mathrm{ART}^{* *}$} & $\mathrm{r}$ & & 159 & .17 & & .163 & & .276 \\
\hline & $\mathrm{p}$ & & .049 & .04 & & .047 & & .035 \\
\hline \multicolumn{9}{|c|}{$\begin{array}{l}\text { *VRT: Visual reaction time } \\
\text { **ART: Auditory reaction time }\end{array}$} \\
\hline \multicolumn{2}{|c|}{ Table 4} & \multicolumn{7}{|c|}{$\begin{array}{l}\text { Change of individual numbers according to } \\
\text { STAl-I score }\end{array}$} \\
\hline Sex & Period & \multicolumn{2}{|c|}{$\begin{array}{l}<36 \\
\text { (no anxiety) }\end{array}$} & \multicolumn{3}{|c|}{$\begin{array}{l}37-42 \\
\text { (mild anxiety) }\end{array}$} & \multicolumn{2}{|c|}{$\begin{array}{l}>42 \\
\text { (high anxiety) }\end{array}$} \\
\hline \multirow[t]{2}{*}{ Male } & Relaxed & 19 & $52.8 \%$ & 7 & 19 & & 10 & $27.8 \%$ \\
\hline & Stressed & 3 & $8.3 \%$ & 6 & 16 & & 27 & $75.1 \%$ \\
\hline \multirow[t]{2}{*}{ Female } & Relaxed & 16 & $53.3 \%$ & 5 & 16 & & 9 & $30.1 \%$ \\
\hline & Stressed & 3 & $10 \%$ & 4 & 13. & & 23 & $76.7 \%$ \\
\hline
\end{tabular}

The number and percentage of the individuals in groups called no anxiety, mild anxiety and high anxiety during relaxed and stressed periods according to STAI-I scores were given in Table 4. According to these data, the number of individuals in high anxiety group were found to increase significantly in stressed period when compared with relaxed period in terms of both males and females (Table 4).

\section{Discussion}

In the current study, cortisol and STAI-I anxiety scores were higher in stressed period when compared with the relaxed period. In addition, there was a positive and weak correlation between cortisol levels and STAI-I scale scores of male and female during the stressed period. This result shows the accuracy of cortisol measurements and that participants are stressed during exams period. It was found that VRT and ART values of males and females who participated in the study increased in stressed period when compared with the relaxed period. It was found that stress had an adverse effect on the sense of VRT and ART. To the best of our knowledge, this is the first study in the literature. When previous studies are examined, the present study seems to be quite unique, which makes it difficult to discuss the results we found.

Stress affects our performance, how we feel and many physical functions (neuro-physiological) [25]. Individuals faced with stress respond with a physiological or psychological response [26]. When compared with relaxed individuals, it has been reported that it is easy for stressed individuals to make mistakes, they are more anxious and uneasy [27]. RT is a significant detail for duties requiring attention. In their studies, Welford [28] and Brebner and Welford [29] stated that individuals moved slower when they were under stress. In the study they conducted, Saha et al., [19] stated that noisy stress decreased VRT and ART.

A great number of researchers state that auditory reaction is faster than visual reaction and average auditory RT's are between 140 and $160 \mathrm{~ms}$, while visual RT's are between 180 and $200 \mathrm{~ms}$ [30, 31]. It was stated that maybe the reason for this 
was the fact that it took about $8-10 \mathrm{~ms}$ for an auditory stimulant to reach the brain $[30,32]$, while it took $20-40 \mathrm{~ms}$ for a visual stimulant [33]. Bellis (34) found VRT as $220 \mathrm{~ms}$ in men and as $260 \mathrm{~ms}$ in women, while ART was found as $190 \mathrm{~ms}$ in men and $200 \mathrm{~ms}$ in women.

In their study, Engel et al. [35], found ART in men as 227 $\mathrm{ms}$ and as $242 \mathrm{~ms}$ in women. Silverman [36] stated that since women drove more carefully recently and that they participated in fast-action sports more, it was possible for them to have a better VRT when compared with men. In their study with lacrosse players, Spierer et al. [37] found that VRT and ART had faster scores in men when compared with women. In a study conducted in Germany, it was stated that in general, women were better than men in handcrafts and ability [38]. In another study conducted, while no significant difference was found between men and women in RT's for visual stimulants, men were found to have faster movement time [39]. In their study, Binboğa et al. [40] found that although men had shorter auditory simple RT than women, the difference was not found to be statistically significant. Gürsoy et al. [41] compared sedentary men and women and found that while right hand visual simple RT of men were found to be significantly shorter, $(p<0.05)$, left hand visual simple RT of men were also found to be shorter, but not significantly $(\mathrm{p}>0.05)$.

Gender is a significant factor in RT. Women have slower RT when compared with men. This time is $30 \%$ shorter in adolescence and maturity. In a study they conducted on 56 females and 57 males between 11 and 14 years of age, Taimela and Kujala concluded that women were slower than men in simple and optional RT's [42].

In every part of life, primarily in educational and business life, individuals who can cope with stress, those who have a high professional efficiency and a high percentage of making right decisions are preferred. Success shown in such situations will put both individuals and institutions a step ahead. The present study has some limitations. First of all, sample size can be larger. However, since we made measurements during students' exam periods and since the measurements took long, we had some problems. Despite all difficulties, a suitable number of participants were included in the power analysis. Secondly, some of the participants in exam stress stated that they got sedatives before measurements in stressed periods and these students were excluded from the study.

\section{Conclusion}

As a conclusion, our study results showed that stress had a negative influence on VRT and ART. This study should be taken into consideration by educators, by individuals who experience exam stress, and by families who think that their children have too much stress in exams. The fact that no similar study was found in our literature research reveals the originality of this study. Exams exist in every moment of our lives and we are faced with important decisions that we have to make at every stage of our lives. The speed, quality and accuracy of the decisions we make are the most important parameters of our success. Considering the results of this study, we should change our perspective on life and remember that excessive stress will negatively affect us. We believe that the present study, which did not have much of a place in literature in detail previously, can be a source for future studies.

Disclosures: There is no conflict of interest for all authors.

\section{Acknowledgement: None}

Funding: None.

\section{References}

1. Dickerson SS, Kemeny ME. Acute stressors and cortisol responses: atheoretical integration and synthesis of laboratory research. Psychol Bull. 2004; 30:355-391. https://doi.org/10.1037/0033-2909.130.3.355.

2. Foley P, Kirschbaum C. Human hypothalamus-pituitary-adrenal axisresponses to acute psychosocial stress in laboratory settings. Neurosci Biobehav Rev. 2010; 35(1):91-96. https://doi.org/10.1016/j.neubiorev.2010.01.010.

3. Shackman AJ, Maxwell JS, McMenamin BW, Greischar LL, Davidson RJ. Stress potentiates early and attenuates late stages of visual processing. J Neurosci. 2011; 31:1156-1161. https://doi.org/10.1523/JNEUROSCI.3384-10.2011.

4. Qi M, Gao H, Guan L, Liu G, Yang J. Subjective Stress, Salivary Cortisol, and Electrophysiological Responses to Psychological Stress. Front Psychol. 2016; 18(7):229. https://doi.org/10.3389/fpsyg.2016.00229.

5. Qin S, Hermans EJ, van Marle HJ, Luo J, Fernández G. Acute psychological stress reduces working memory-related activity in the dorsolateral prefrontal cortex. Biol Psychiatry. 2009; 66(1):25-32. https://doi.org/10.1016/j.biopsych.2009.03.006.

6. Sandi C, Haller J. Stress and the social brain: behavioural effects and neurobiological mechanisms. Nat Rev Neurosci. 2015; 16(5):290304. https://doi.org/10.1038/nrn3918.

7. Kiecolt-Glaser JK, McGuire L, Robles TF, Glaser R. Psychoneuroimmunology and psychosomatic medicine: back to the future. Psychosom Med. 2002; 64(1):15-28. https://doi.org/10.1097/00006842-200201000-00004.

8. Lazarus R, Folkman S. Stress, appraisal and coping. New York: Springer. 1984. https://doi.org/10.1007/978-1-4419-1005-1009

9. Liebert RM, Morris LW. Cognitive and emotional components of test anxiety: a distinction and some initial data. Psychol Rep. 1967; 20(3):975-978. https://doi.org/10.2466/pr0.1967.20.3.975.

10. Spielberger CD, Vagg PR. Test anxiety: a transactional process model. In: Spielberger CD, Vagg PR, editors. Test anxiety: theory, assessment, and treatment. Washington: Taylor and Francis. 1995; 3-14.

11. Lindahl M, Theorell T, Lindblad F. Test performance and self-esteem in relation to experienced stress in Swedish sixth and ninth graders-saliva cortisol levels and psychological reactions to demands. Acta Paediatr. 2005; 94(4):489-495. https://doi. org/10.1111/j.1651-2227.2005.tb01922.x

12. Yenice E. Performans Ölçümünde Karşılaşılan Sorunlar ve Kurumsal Karne (Balanced Scorecard) Yaklaşımı. Bütçe Dünyası. 2007; 2(25):95-100.

13. Barlı Ö. Davranış Bilimleri ve Örgütlerde Davranış, 4. Baskı, Aktif Yayınevi, Erzurum. 2010.

14. Soysal A. Farklı Sektörlerde Çalışan İşgörenlerde Örgütsel Stres Kaynakları: Kahramanmaraş ve Gaziantep’te Bir Araştırma. The Journal of Faculty of Economics and Administrative Sciences. 2009; 14(2):333-359. 
15. Hick WE. On the rate of gain of information. Q J Exp Psychol. 1952; 4:11-26. https://doi.org/10.1080/17470215208416600

16. Bunce D, MacDonald SW, Hultsch DF. Inconsistency in serial choice decision and motor reaction times dissociate in younger and older adults. Brain Cogn. 2004; 56(3):320-327. https://doi.org/10.1016/j.bandc.2004.08.006

17. Duvan A, Toros T, Şenel Ö. Effects of maximum exercise intensity on visual reaction time of elite fencers. Niğde Üniversitesi Beden Ĕgitimi ve Spor Bilimleri Dergisi. 2010; 4(3):146-511.

18. Ganong WF. Review of Medical Physiology. San Francisco. McGraw-Hill. 2001; 49-51.

19. Saha S, Gandhi A, Das S, Kaur P, Singh SH. Effect of noise stress on some cardiovascular parameters and audiovisual reaction time. Indian J Physiol Pharmacol. 1996; 40(1):35-40. PMID: 8864769.

20. Panayiotou G, Vrana SR. The role of self-focus, task difficulty, task self-relevance, and evaluation anxiety in reaction time performance. Motivation and Emotion. 2004; 28(2):171-196. https://doi.org/10.1023/B:MOEM.0000032313.69675.0d.

21. Ozgocer T, Ucar C, Yildiz S. Cortisol awakening response is blunted and pain perception is increased during menses in cyclic women. Psychoneuroendocrinology. 2017; 77:158-164. https://doi.org/10.1016/j.psyneuen.2016.12.011.

22. Öner N, Le Compte A. Durumluk-Sürekli Kaygı Envanteri El Kitabı. İstanbul: Boğaziçi Üniversitesi Yayını. 1983.

23. Tamer K. Sporda Fiziksel-Fizyolojik Performans Ölçülmesi ve Değerlendirilmesi Ankara: Türker Kitabevi. 1995.

24. Granger DA, Kivlighan KT, el-Sheikh M, Gordis EB, Stroud LR. Salivary alpha-amylase in biobehavioral research: recent developments and applications. Ann N Y Acad Sci. 2007; 1098:122-144. https://doi.org/10.1196/annals.1384.008.

25. Mathews A, MacLeod C. Induced processing biases have causal effects on anxiety. Cognition \& Emotion. 2002; 16: 331-354. https:// doi.org/10.1080/02699930143000518

26. Apoorvagiri D, Nagananda MS. Mental Stress and its Implications on Reaction time. IJCTT. 2013; 4(5):1426-1430.

27. Preuss D, Schoofs D, Schlotz W, Wolf OT. The stressed student: influence of written examinations and oral presentations on salivary cortisol concentrations in university students. Stress. 2010; 13(3):221-229. https://doi.org/10.3109/10253890903277579

28. Welford AT. Choice reaction time: Basic concepts. In A. T. Welford (Ed.), Reaction Times. Academic Press, New York. 1980; 73-128.

29. Brebner JT, Welford AT. Introduction: an historical background sketch. In A. T. Welford (Ed.), Reaction Times, Academic Press, New York. 1980; 1-23.

30. Teichner WH, Krebs MJ. Laws of visual choice reaction time. Psychol Rev. 1974; 81(1):75-98. https://doi.org/10.1037/h0035867.

31. Luce RD. Response Times: Their Role in Inferring Elementary Mental Organization. Oxford University Press, New York. 1986.

32. Kemp BJ. Reaction time of young and elderly subjects in relation to perceptual deprivation and signal-on versus signal-off condition. Dev Psychol. 1973; 8(2): 268-272.

33. Marshall WH, Talbot SA, Ades HW. Cortical response of the anaesthetized cat to gross photic and electrical afferent stimulation. $J$ Neurophysiol. 1943; 6:1-15. https://doi.org/10.1152/jn.1943.6.1.1.

34. Bellis CJ. Reaction time and chronological age. Proceedings of the Society for Experimental Biology \& Medicine. 1933; 30:801-803. https://doi.org/10.3181/00379727-30-6682.

35. Engel BT, Thorne PR, Quilter RE. On the relationships among sex, age, response mode, cardiac cycle phase, breathing cycle phase, and simple reaction time. J Gerontol. 1972; 27(4):456-460. https://doi.org/10.1093/geronj/27.4.456

36. Silverman IW. Sex Differences in Simple Visual Reaction Time: A Historical Meta-Analysis. Sex Roles. 2006; 54(1-2):57-69. https:// doi.org/10.1007/s11199-006-8869-6

37. Spierer DK, Petersen RA, Duffy K, Corcoran BM, Rawls-Martin T. Gender influence on response time to sensory stimuli. $J$ Strength Cond Res. 2010; 24(4):957-963. https://doi.org/10.1519/JSC.0b013e3181c7c536.

38. Dündar U. Antrenman Teorisi. Ankara, Bağırgan Yayınevi. 1997.

39. Gündüz N. Antrenman bilgisi. İzmir: Saray Tip Kitabevleri. 1997.

40. Binboğa E, Pehlivan M, Çelebi G. The effects of auditory stimuli with varying frequency and intensitiy on human simple reaction time. Ege Journal of Medicine. 2007; 46(2):67-72.

41. Gürsoy R, Akarsu S, Hazar K. Examination of correlation among reaction time, strength, and flexibility of sedentary and athletes in different branches. Journal of Human Sciences. 2017; 14(4):3282-3291. https://doi.org/10.14687/jhs.v14i4.4786.

42. Taimela S, Kujala UM. Reaction times with reference to musculoskeletal complaints in adolescence. Percept Mot Skills. 1992; 75(3 Pt 2):1075-1082. https://doi.org/10.2466/pms.1992.75.3f.1075. 